\title{
Vertical Patterns of Early Summer Chlorophyll a Concentration in the Indian Ocean with Special Reference to the Variation of Deep Chlorophyll Maximum
}

\author{
Gang Li, ${ }^{1}$ Qiang Lin, ${ }^{1}$ Guangyan Ni, ${ }^{2}$ Pingping Shen, ${ }^{1}$ Yanzhi Fan, ${ }^{1}$ \\ Liangmin Huang, ${ }^{1}$ and Yehui Tan ${ }^{1}$ \\ ${ }^{1}$ Key Laboratory of Marine Bio-Resources Sustainable Utilization, South China Sea Institute of Oceanology, CAS, \\ Guangzhou 510301, China \\ ${ }^{2}$ Key Laboratory of Vegetation Restoration and Management of Degraded Ecosystems, South China Botanical Garden, CAS, \\ Guangzhou 510160, China
}

Correspondence should be addressed to Yehui Tan, tanyh@scsio.ac.cn

Received 3 June 2012; Revised 2 July 2012; Accepted 11 July 2012

Academic Editor: E. A. Pakhomov

Copyright (C) 2012 Gang Li et al. This is an open access article distributed under the Creative Commons Attribution License, which permits unrestricted use, distribution, and reproduction in any medium, provided the original work is properly cited.

\begin{abstract}
Vertical patterns of early summer chlorophyll $a(\mathrm{Chl} a)$ concentration from the Indian Ocean are presented, as well as the variations of depth and size-fractioned Chl $a$ in the deep chlorophyll maximum (DCM). A total of 38 stations were investigated from 12 April to 5 May 2011, with 8 discrete-depth samples ( 7 fixed and 1 variable at real DCM) measured at each station. Depth-integrated Chl a concentration $\left(\sum \mathrm{Chl} a\right.$ ) varied from 11.5 to $26.8 \mathrm{mg} \mathrm{m}^{-2}$, whereas Chl $a$ content at DCM ranged from 0.17 to $0.57 \mu \mathrm{g} \mathrm{L}^{-1}$ with picophytoplankton $(<3 \mu \mathrm{m})$ accounting for $82 \%$ to $93 \%$. The DCM depth varied from 55.6 to $91 \mathrm{~m}$ and shoaled latitudinally to northward. Moreover, our results indicated that the $\sum \mathrm{Chl} a$ could be underestimated by up to $9.3 \%$ with a routine sampling protocol of collecting samples only at 7 fixed depths as the real DCM was missed. The underestimation was negatively correlated to the DCM depth when it varied from 55.6 to $71.3 \mathrm{~m}(r=-0.63, P<0.05)$ but positively correlated when it ranged from 75.8 to $91 \mathrm{~m}(r=0.68, P<0.01)$. This indicates that in the Indian Ocean the greater the departure of the DCM from $75 \mathrm{~m}$ depth, the greater the underestimation of integrated $\mathrm{Chl} a$ concentration that could occur if the real DCM is missed.
\end{abstract}

\section{Introduction}

Photosynthetic marine phytoplankton species play a pivotal role in oceanic biological processes, producing particulate and dissolved organic carbon [1]. Such photosynthetic processes also reduce the partial pressure of $\mathrm{CO}_{2}$ in surface seawater and ultimately result in the drawdown of atmospheric $\mathrm{CO}_{2}$ [2]. In surface oceans, a series of environmental factors are known to control the biomass and distribution of phytoplankton. Light intensity influences phytoplankton growth and productivity through driving or photoinhibiting photosynthesis $[3,4]$, while vertical mixing affects carbon fixation ability by balancing the damage and repair at high or low light levels [5, 6]. The available trace metals (e.g., copper and iron) also lead to variations in phytoplankton biomass or size communities [7-9]. The temperature that often regulates surface ocean stratification can reduce the exchange of nutrients between deep nutritious water and surface water, depressing nutrient status within the euphotic zone and influencing species composition [10]. Changes in physicochemical environments (e.g., light, mixing, temperature, or nutrients) would thus influence phytoplankton community structure and alter their vertical distributions in the water column $[10,11]$.

In pelagic oceans, the deep chlorophyll maximum (DCM) that appears between the nutrient-depleted upper and light-limited lower layers of the euphotic zone is usually characterized by high phytoplankton biomass and production [12-15]. Contributions of the DCM to integrated chlorophyll $a(\mathrm{Chl} a)$ and primary production have been estimated up to $90 \%$ and $30 \%$ of total $[12,13]$. As a result, many studies tend to focus on the DCM layer 


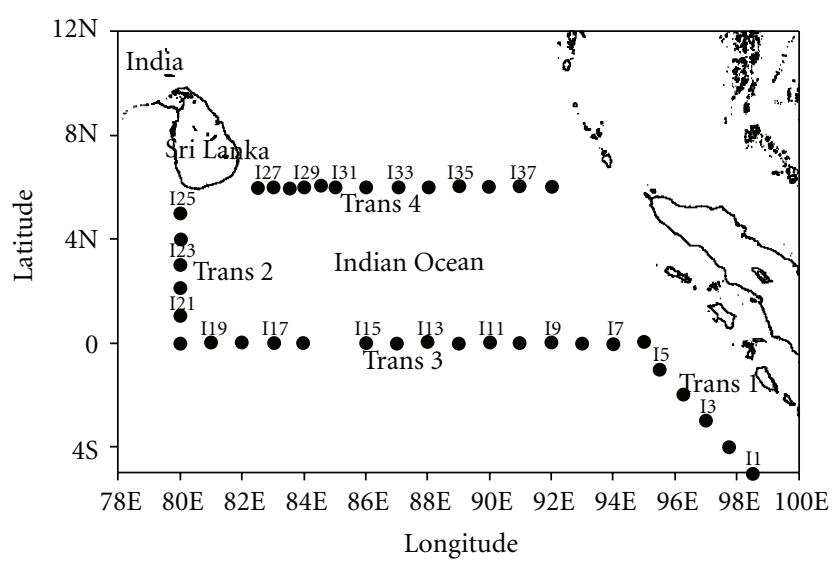

FIGURE 1: Map of the Indian Ocean, showing the sampling sites (solid circles) during the cruise dated from 12 April to 4 May, 2011.

in marine investigations, for example, in the South China Sea $[10,16]$, Atlantic or Pacific Oceans [15, 17]. Regionally, the Indian Ocean hosts a unique oceanographic process caused by semiannually reversing monsoon winds [1820], leading to a great variation in vertical stability and nutrients fluxes as well as depth of upper mixed layer (UML) [21-23]. Corresponding to such changes in mixed layer depth and nutrient regeneration, thickness and depth of the DCM therein would be changed greatly [24, 25], as well as phytoplankton community structure [15]. It is of general interest to understand such biological characteristics of the DCM; however, little has been documented in the Indian Ocean [15]. In this study, we investigated the vertical patterns of Chl $a$ concentration in this tropical region and looked into the size communities of the DCM layer.

\section{Materials and Methods}

2.1. Study Area and Sampling Protocol. During a cruise dated from 12 April to 4 May 2011, we measured the profiles of chlorophyll $a(\mathrm{Chl} a)$ concentration in the Indian Ocean. A total of 38 stations were settled at intervals of 55 to $110 \mathrm{~km}$ along four transacts: transacts 1,2 in latitude and transacts 3,4 in longitude (Figure 1). At each station, discrete seawater samples were collected from 7 fixed depths $(0 \mathrm{~m}$, $25 \mathrm{~m}, 50 \mathrm{~m}, 75 \mathrm{~m}, 100 \mathrm{~m}, 150 \mathrm{~m}$, and $200 \mathrm{~m}$ ) with a Rosette sampler fitted with $5 \mathrm{~L}$ Niskin Bottles and mounted on a SeaBird Electronics CTD (SBE-911 plus, USA); this sampling protocol is broadly used (e.g., $[26,27])$. To vividly track the variable deep chlorophyll a maximum (DCM), one more water sample was taken from a depth of maximal fluorescence that was determined by a CTD-mounted fluorometer (termed hereafter real DCM). All 8 collected samples were treated within $10 \mathrm{~min}$ for determination of $\mathrm{Chl} a$ content and phytoplankton species composition as described below.

2.2. Chl a Determination. To determine $\mathrm{Chl} a$ concentration, $800 \mathrm{~mL}$ seawater from each depth of each station was filtered onto a Whatman GF/F glass fiber filter $(25 \mathrm{~mm})$, which was immediately wrapped in aluminum foil, frozen, and stored at $-20^{\circ} \mathrm{C}$ for later extraction and measurement. The content of Chl $a$ was measured fluorescently using a Turner Design 10 fluorometer after a complete extraction with $90 \%$ acetone $(\mathrm{v} / \mathrm{v})$ for $24 \mathrm{~h}$ in the dark at $4^{\circ} \mathrm{C}$. Chl $a$ concentration was calculated according to Parsons et al. [28]. For determination of picophytoplankton cells fraction $(<3 \mu \mathrm{m})$, prefiltered $(3 \mu \mathrm{m}$ pore-size polycarbonate filter) samples were filtered onto a Whatman GF/F filter, and the measurement of Chl $a$ was performed as described above.

2.3. Species Analyses. For phytoplankton species analyses, the seawater sample was fixed with Lugol's solution to a final concentration of $1.5 \%$ [28]. After one-liter sample was concentrated to $30 \mathrm{~mL}$ by settling for $24 \mathrm{~h}$ and gently siphoning supernatant, identification and numeration of the species were conducted under a regular microscope for a whole $0.5 \mathrm{~mL}$ sample with Utermöhl's method [29].

2.4. Data Analysis. Chl a concentration of the water column was integrated as [30]

$$
\sum \operatorname{Chl} a=\int_{0}^{200}[\mathrm{Chl} a]
$$

where $\sum \operatorname{Chl} a\left(\mathrm{mg} \mathrm{m}^{-2}\right)$ is the depth-integrated Chl $a$ concentration, whereas [Chl $a$ ] is the $\mathrm{Chl} a$ concentration $\left.(\mu \mathrm{g} \mathrm{L})^{-1}\right)$ at one depth.

Underestimation (\%) of the depth-integrated Chl $a$ when missing the real DCM was calculated as

$$
\operatorname{Uest}(\%)=\frac{\left(\sum \operatorname{Chl} a-\sum^{\prime} \operatorname{Chl} a\right)}{\sum \operatorname{Chl} a} \times 100 \%
$$

where Uest (\%) is the underestimation of depth-integrated Chl $a$ due to the real DCM missing and $\sum \mathrm{Chl} a$ and $\sum^{\prime} \mathrm{Chl} a$ $\left(\mathrm{mg} \mathrm{m}^{-2}\right)$ are the depth-integrated Chl $a$ calculated using the Chl $a$ density collected from 7 fixed and 1 variable depths (i.e., real DCM) or just using that from 7 fixed depths (miss the real DCM), respectively.

We combined data from transacts 1 and 2 together in Figure 2 to more clearly show a latitudinal variation of 


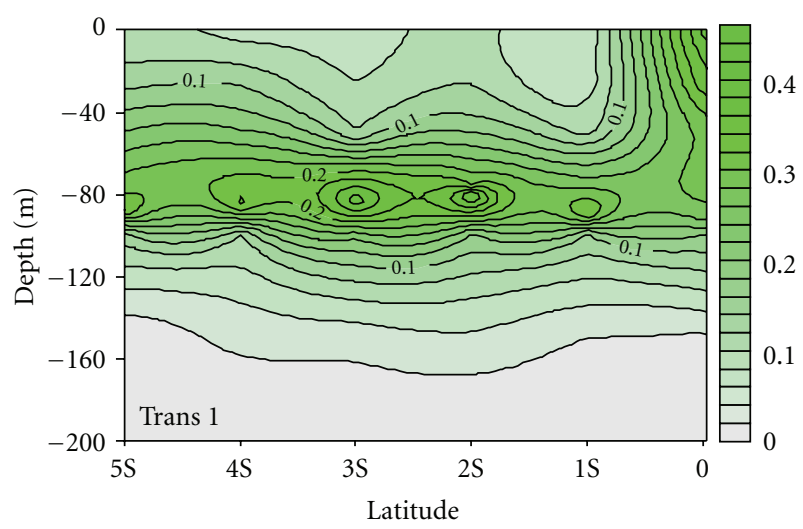

(a)

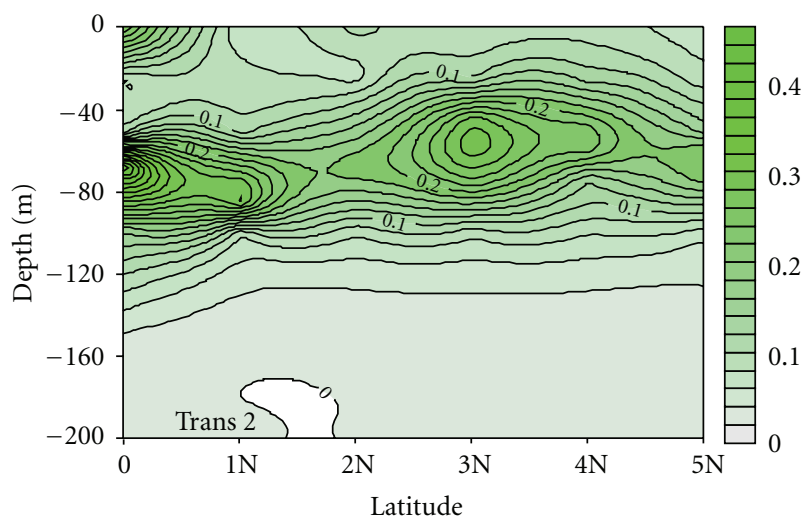

(b)

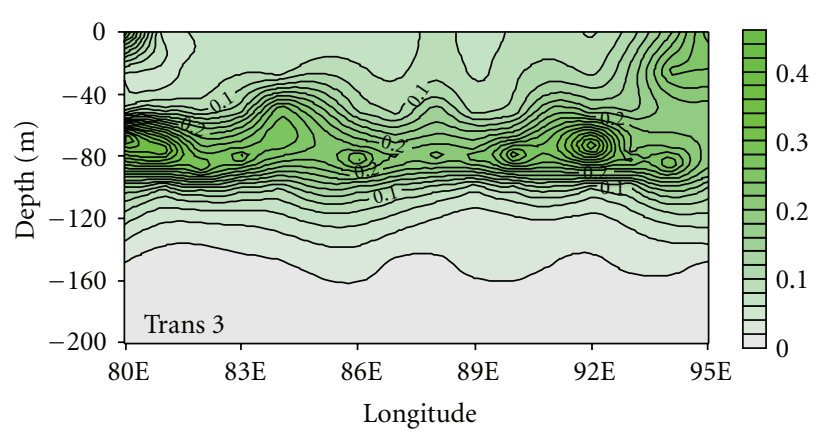

(c)

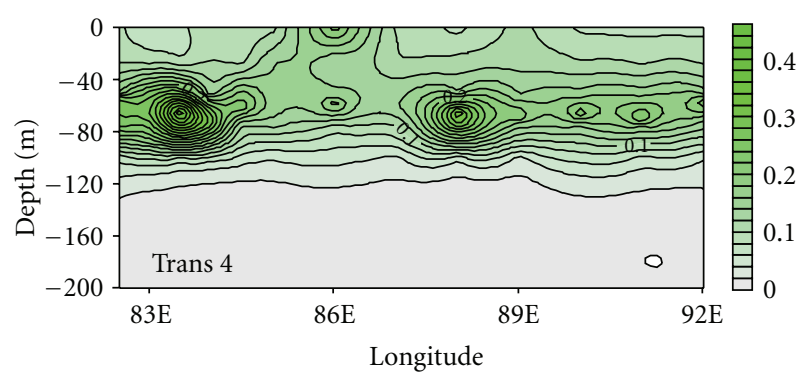

(d)

FIgURE 2: Vertical patterns of chlorophyll a concentration (Chl $a, \mu \mathrm{g} \mathrm{L}^{-1}$ ) along the four transacts, showing the variations in the latitudinal ((a) and (b)) and longitudinal ((c) and (d)) scales.

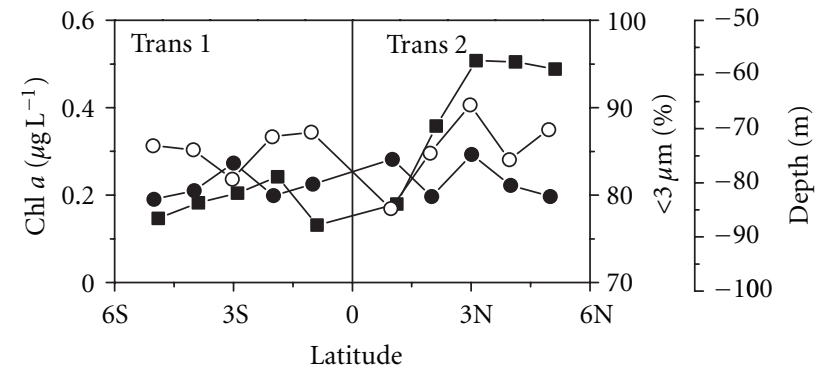

(a)

(b)

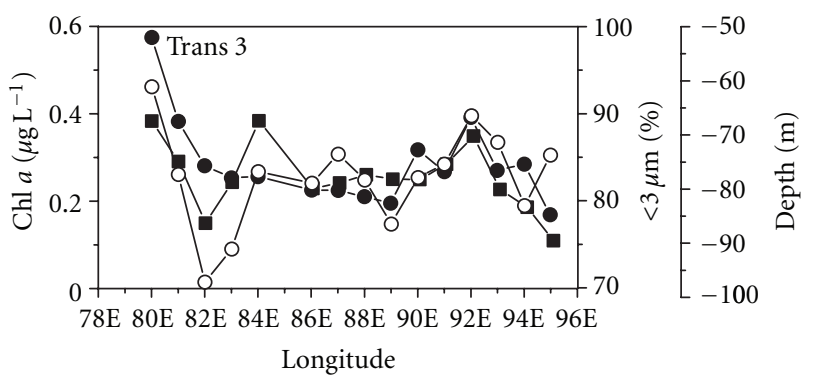

(c)

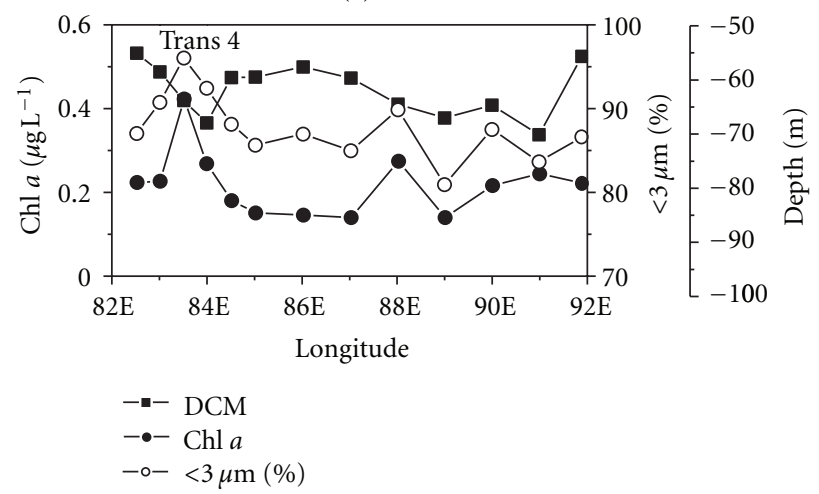

(d)

FIgure 3: Variability of the Chl $a$ concentration $\left(\mu \mathrm{g} \mathrm{L}^{-1}\right)$, proportion of picocells fraction (\%) and depth (m) of the DCM: in latitude ((a) and (b)) and longitude ((c) and (d)).

Chl a. One-way analysis of variance (ANOVA) was used to determine the significant differences among the estimated parameters $(P<0.05)$; the correlation between variables was established using a Kendall's $t$-test with $95 \%$ confidence band.

\section{Results}

Contours of Chl $a$ for the four transacts in the Indian Ocean throughout 12 April to 4 May 2011 are shown in Figure 2. Chl a concentration displayed a drastic change with increasing depth, with surface values being less than $0.10 \mu \mathrm{g} \mathrm{L}^{-1}$ in most cases (except at stations I6 and I20); it increased to a maximum of over $0.20 \mu \mathrm{g} \mathrm{L}^{-1}$ at the DCM and then decreased to less than $0.01 \mu \mathrm{g} \mathrm{L}^{-1}$ at the bottom (Figure 2). The most conspicuous feature relating to the pattern of vertical Chl a distribution was the location of the DCM, which varied greatly and shoaled latitudinally to northward (Figures 2(a) and 2(b)). 
Great variability of Chl a content at the DCM as well as its depth was found for the study period (Figure 3 ). Chl $a$ varied greatly from 0.17 to $0.57 \mu \mathrm{g} \mathrm{L}^{-1}$ at stations I35 and I20, respectively, where picophytoplankton $(<3 \mu \mathrm{m})$ accounted for $82 \%$ and $93 \%$ of total Chl a (Figure 3 ). Most of the microscopically identified phytoplankton groups were dinoflagellates (e.g., Amphidinium carterae, Gyrodinium spp., Gonyaulax spp. and Prorocentrum sp.) and diatoms (e.g., Chaetoceros spp.), although the cyanobacterium Trichodesmium hildebrandtii was numerically important at some stations (e.g., I6 and I7). In particular, depth of the DCM displayed a high variability in a latitudinal scale and shoaled from 91 to $55.6 \mathrm{~m}$ to northward (Figures 3(a) and $3(\mathrm{~b})$ ); however, less variability was shown in a longitudinal scale (Figures 3(c) and 3(d)). The DCM depth in transact 3 (equatorial water) was $79 \pm 6.4 \mathrm{~m}$, approximately $16 \mathrm{~m}$ deeper than that of transact $4\left(6^{\circ} \mathrm{N}\right.$ water, $\left.63 \pm 5.0 \mathrm{~m}\right)$ (Figures 3(c) and 3(d)).

Depth-integrated Chl $a$ concentration $\left(\sum \mathrm{Chl} a\right)$ ranged from 11.5 to $26.8 \mathrm{mg} \mathrm{m}^{-2}$ if including the real DCM at stations I32 and I7, respectively (Figure 4(a)). Exclusion of the real DCM caused $0.65 \%$ to $9.3 \%$ underestimation of the $\sum$ Chl $a$ (Figure 4(b)) where the depths of DCM were $75.8 \mathrm{~m}$ (I10) and $91 \mathrm{~m}$ (I5), respectively. A significant relationship was found when the underestimated $\sum \mathrm{Chl} a$ was plotted against the DCM depth (Figure 4(b)), that is, the underestimation was negatively correlated to the depth when it varied from 55.6 to $71.3 \mathrm{~m}(r=-0.63, P<0.05)$ and positively correlated when it ranged from 75.8 to $91 \mathrm{~m}$ ( $r=0.68, P<0.01)$. This indicates that a greater departure of the DCM from $75 \mathrm{~m}$ would cause a greater underestimation of primary production if the real DCM is missed as seen in previous investigations where samples were collected at only 7 fixed depths.

\section{Discussion}

In this paper, we present the vertical patterns of chlorophyll a concentration in the Indian Ocean, where the DCM depth shoaled latitudinally to northward. The routine depthintegrated $\mathrm{Chl} a$ content as reported previously (e.g., [26, 27]) could be underestimated by up to $9.3 \%$ due to missing of the real DCM. The underestimation was negatively correlated to the DCM depth if it was less than $75 \mathrm{~m}$ but positively correlated if it was over $75 \mathrm{~m}$.

The DCM layers frequently appear in oligotrophic waters of the Indian Ocean over the summer period, with a high variability in depth and magnitude as shown here (Figures 2-4) or in other studies [10, 15, 31]. Changes in water turbulence, nutrient-flux, and light intensity could be responsible for the changes in DCM location, thickness, and Chl a content. In the investigated water, seasonal transition of southwest to northeast monsoons underwent a drastic vertical turbulence in the water column [20, 21, 23]. Dynamics of the mixed layer caused by winds, together with eddies, influenced the supply of nutrients from below the thermocline, powering the growth of phytoplankton and ultimately affecting the DCM formation and maintenance (i.e., biomass and distribution) $[15,23,31,32]$. Moreover, nutrients, for example, biogenic silica, that are often speciesspecific could be another cause for the presence of diatom populations at the DCM [33]. Solar radiation that provides energy for photosynthesis could also regulate phytoplankton community structure and locations in the euphotic zone $[17,34]$. This might also explain the more shallow DCM depth in the $6^{\circ} \mathrm{N}$ waters compared to equatorial waters in the Indian Ocean (Figures 3(c) and 3(d)), as well as its latitudinal shoaling to northward during the early summer period (Figures 3(a) and 3(b)).

The proportion of small picophytoplankton markedly decreased with the DCM depth (Figure 5). Solar irradiation was known to be lower at the DCM with much more short-waveband blue light [35]; only larger phytoplankton cells can utilize short-waveband energy for photosynthesis $[4,36]$. Growth of smaller cells at this layer might thus be inferior to their larger counterparts, leading to a negative correlation of pico-cells in proportion to the DCM depth $(r=-0.53, P<0.01)$. On the other hand, the nutrient status in the DCM was usually pulsed-supplied by vertical mixing $[32,37]$; therefore, the growth of larger plankton cells could be superior to smaller ones due to their possession of nutrient storage vacuoles [38], resulting in the higher proportion in deeper DCM (Figure 5). Atmospheric conditions such as cloudiness could be another cause for the variation of DCM locations [22]; however, sunny days prevailed over the investigated waters during the study period, and the cloudiness would thus have had little effect on the locations of DCM.

Depth, thickness, and Chl a content of the DCM often change greatly in the spatial (Figures 2 and 3 ) or temporal scales $[15,16,21]$ due to the changes in environmental factors [31, 34, 37]. Considering that the DCM contributes to a large portion of total primary production $[12,13]$, the depth-integrated biomass of phytoplankton tended to be underestimated if missing the real DCM using the routine sampling protocol of collecting samples at only several fixed depths. According to our results, the depth-integrated Chl $a$ could be underestimated by up to $9.3 \%$ due to missing the real DCM in the Indian Ocean; it could be higher when the DCM location departs more from $75 \mathrm{~m}$ depth.

\section{Acknowledgments}

The authors are thankful for the comments and suggestions of the anonymous reviewers and of the editors that helped to improve their paper. This work was supported by the National Natural Science Foundation (no. 411355), Natural Science Foundation of Guangdong (no. S2011040 000151), CAS Knowledge Innovation Program (no. SQ20 115), National Project of Sciences and Technology (no. 2008FY110100), and the Key Innovation Group Project (no. KZCX2-YW-Q07) and Strategic Pilot Science and Technology (no. XDA05030403) of CAS. Thanks are also given to Miranda Corkum for polishing the English in this manuscript, to Zhixin Ke, Kaizhi Li, Shengfu Wang, and 


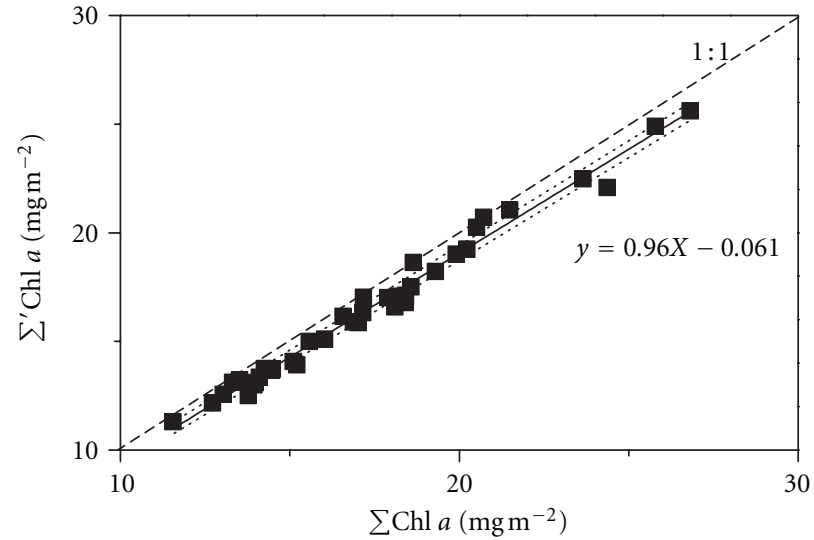

(a)

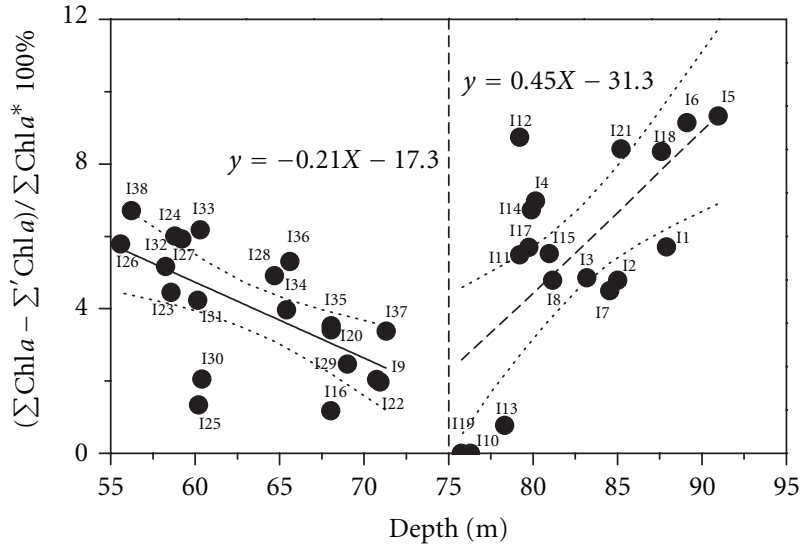

(b)

FIGURE 4: (a) Integrated $\mathrm{Chl} a\left(\sum^{\prime} \mathrm{Chl} a, \mathrm{mg} \mathrm{m}^{-2}\right)$ not including the real DCM as a function of that including it $\left(\sum \mathrm{Chl} a\right)$, with the solid line showing the significant relationships $(r=0.99, P<0.01, n=38)$. (b) The underestimated $\sum \mathrm{Chl} a(\%)$ when missing the real DCM as a function of its depth $(\mathrm{m})$, with the lines indicating the significant relationship (solid line, $r=-0.63, P<0.05, n=20$; dashed line, $r=0.68$, $P<0.01, n=18)$.

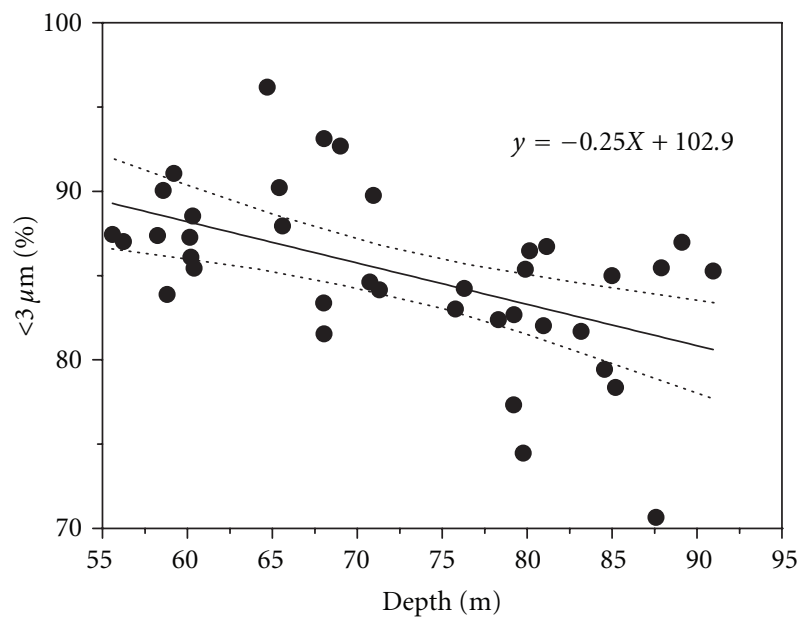

Figure 5: Contribution (\%) of picocells fraction to total Chl $a$ at the DCM as a function of the DCM depth. The solid line shows the significant relationship $(r=-0.53, P<0.01, n=38)$.

Shuai Xing for their experimental assistance, and to the captain and crews of Shiyan I ship for logistic support.

\section{References}

[1] C. B. Field, M. J. Behrenfeld, J. T. Randerson, and P. Falkowski, "Primary production of the biosphere: integrating terrestrial and oceanic components," Science, vol. 281, no. 5374, pp. 237240, 1998.

[2] H. Wu, D. Zou, and K. Gao, "Impacts of increased atmospheric $\mathrm{CO}_{2}$ concentration on photosynthesis and growth of micro- and macro-algae," Science in China C, vol. 51, no. 12, pp. 1144-1150, 2008.

[3] K. Gao, P. Li, T. Watanabe, and E. Walter Helbling, "Combined effects of ultraviolet radiation and temperature on morphology, photosynthesis, and DNA of Arthrospira (Spirulina)
Platensis (Cyanophyta)," Journal of Phycology, vol. 44, no. 3, pp. 777-786, 2008.

[4] G. Li, K. Gao, and G. Gao, "Differential impacts of solar UV radiation on photosynthetic carbon fixation from the coastal to offshore surface waters in the south China sea," Photochemistry and Photobiology, vol. 87, no. 2, pp. 329-334, 2011.

[5] E. W. Helbling, K. Gao, R. J. Gonçalves, H. Wu, and V. E. Villafañe, "Utilization of solar UV radiation by coastal phytoplankton assemblages off SE China when exposed to fast mixing," Marine Ecology Progress Series, vol. 259, pp. 59-66, 2003.

[6] G. Li and K. Gao, "Variation in UV irradiance related to stratospheric ozone levels affects photosynthetic carbon fixation of winter phytoplankton assemblages in the South China sea," Marine Biology Research, vol. 8, pp. 670-676, 2012.

[7] L. E. Brand, W. G. Sunda, and R. R. L. Guillard, "Reduction of marine phytoplankton reproduction rates by copper and cadmium," Journal of Experimental Marine Biology and Ecology, vol. 96, no. 3, pp. 225-250, 1986.

[8] E. W. Helbling, V. Villafane, and O. Holm-Hansen, "Effect of iron on productivity and size distribution of Antarctic phytoplankton," Limnology and Oceanography, vol. 36, no. 8, pp. 1879-1885, 1991.

[9] V. M. Franck, G. J. Smith, K. W. Bruland, and M. A. Brzezinski, "Comparison of size-dependent carbon, nitrate, and silicic acid uptake rates in high- and low-iron waters," Limnology and Oceanography, vol. 50, no. 3, pp. 825-838, 2005.

[10] Y. L. Lee Chen and H. Y. Chen, "Seasonal dynamics of primary and new production in the northern South China sea: the significance of river discharge and nutrient advection," DeepSea Research I, vol. 53, no. 6, pp. 971-986, 2006.

[11] B. Wang and Z. Wang, "Long-term variations in chlorophyll a and primary productivity in Jiaozhou Bay, China," Journal of Marine Biology, vol. 2011, Article ID 594684, 7 pages, 2011.

[12] M. Estrada, "Deep phytoplankton and chlorophyll maxima in Western Mediterranean," in Mediterranean Marine Ecosystems, M. Moraitou-Apostolopoulou and V. Kiortsis, Eds., pp. 247277, Plenum Press, New York, NY, USA, 1985. 
[13] J. M. Gasol, J. García-cantizano, R. Massana, R. Guerrero, and C. Pedrós-alió, "Physiological ecology of a metalimnetic Cryptomonas population: relationships to light, sulfide and nutrients," Journal of Plankton Research, vol. 15, no. 3, pp. 255-275, 1993.

[14] E. Marañón, P. M. Holligan, R. Barciela et al., "Patterns of phytoplankton size structure and productivity in contrasting open-ocean environments," Marine Ecology Progress Series, vol. 216, pp. 43-56, 2001.

[15] G. Li, Z. Ke, Q. Lin et al., "Longitudinal patterns of springintermonsoon phytoplankton biomass, species compositions and size structure in the Bay of Bengal," Acta Oceanologica Sinica, vol. 31, pp. 121-128, 2012.

[16] X. Ning, F. Chai, H. Xue, Y. Cai, C. Liu, and J. Shi, "Physicalbiological oceanographic coupling influencing phytoplankton and primary production in the South China sea," Journal of Geophysical Research C, vol. 109, no. 10, Article ID C10005, 20 pages, 2004.

[17] G. C. Anderson, "Subsurface chlorophyll maximum in the Northeast Pacific ocean," Limnology and Oceanography, vol. 14, pp. 386-391, 1969.

[18] S. R. Shetye, A. D. Gouveia, D. Shankar et al., "Hydrography and circulation in the western Bay of Bengal during the northeast monsoon," Journal of Geophysical Research C, vol. 101, no. 6, pp. 14011-14025, 1996.

[19] N. V. Madhu, R. Jyothibabu, P. A. Maheswaran, V. John Gerson, T. C. Gopalakrishnan, and K. K. C. Nair, "Lack of seasonality in phytoplankton standing stock (chlorophyll $a$ ) and production in the western Bay of Bengal," Continental Shelf Research, vol. 26, no. 16, pp. 1868-1883, 2006.

[20] F. C. Bassinot, C. Marzin, P. Braconnot et al., "Holocene evolution of summer winds and marine productivity in the tropical Indian ocean in response to insolation forcing: datamodel comparison," Climate of the Past, vol. 7, no. 3, pp. 815829, 2011.

[21] M. J. W. Veldhuis, G. W. Kraay, J. D. L. Van Bleijswijk, and M. A. Baars, "Seasonal and spatial variability in phytoplankton biomass, productivity and growth in the northwestern Indian ocean: the southwest and northeast monsoon, 1992-1993," Deep-Sea Research I, vol. 44, no. 3, pp. 425-449, 1997.

[22] K. Banse, "Clouds, deep chlorophyll maxima and the nutrient supply to the mixed layer of stratified water bodies," Journal of Plankton Research, vol. 9, no. 5, pp. 1031-1036, 1987.

[23] S. P. Kumar, M. Nuncio, N. Ramaiah et al., "Eddy-mediated biological productivity in the Bay of Bengal during fall and spring intermonsoons," Deep-Sea Research I, vol. 54, no. 9, pp. 1619-1640, 2007.

[24] T. G. Coon, M. M. Lopez, P. J. Richerson, T. M. Powell, and C. R. Goldman, "Summer dynamics of the deep chlorophyll maximum in Lake Tahoe," Journal of Plankton Research, vol. 9, no. 2, pp. 327-344, 1987.

[25] V. S. N. Murty, G. V. M. Gupta, V. V. Sarma et al., "Effect of vertical stability and circulation on the depth of the chlorophyll maximum in the Bay of Bengal during May-June, 1996," Deep-Sea Research I, vol. 47, no. 5, pp. 859-873, 2000.

[26] S. Gao, H. Wang, G. Liu, and L. Huang, "The statistical estimation of the vertical distribution of chlorophyll a concentration in the South China sea," Journal of Tropical Oceanography, vol. 32, pp. 168-176, 2010 (Chinese).

[27] B. Huang, W. Lan, Z. Cao et al., "Spatial and temporal distribution of nanoflagellates in the northern South China sea," Hydrobiologia, vol. 605, no. 1, pp. 143-157, 2008.
[28] T. R. Parsons, Y. Maita, and C. M. Lalli, A Manual of Chemical and Biological Methods for Seawater Analysis, Pergamon Press, Toronto, Canada, 1984.

[29] H. Utermöhl, "Toward the improvement of the quantitative phytoplankton method," Mitteilungen-Internationale Vereiningung fur Limnologie, vol. 9, pp. 1-38, 1958.

[30] M. J. Behrenfeld and P. G. Falkowski, "A consumer's guide to phytoplankton primary productivity models," Limnology and Oceanography, vol. 42, no. 7, pp. 1479-1491, 1997.

[31] R. J. W. Brewin, T. Hirata, N. J. Hardman-Mountford, S. J. Lavender, S. Sathyendranath, and R. Barlow, "The influence of the Indian ocean dipole on interannual variations in phytoplankton size structure as revealed by Earth observation ," Deep-Sea Research. In press.

[32] R. A. Varela, A. Cruzado, J. Tintore, and E. Garcia Ladona, "Modelling the deep-chlorophyll maximum: a coupled physical- biological approach," Journal of Marine Research, vol. 50, no. 3, pp. 441-463, 1992.

[33] G. V. M. Gupta and V. V. Sarma, "Biogenic silica in the Bay of Bengal during the southwest monsoon," Oceanologica Acta, vol. 20, no. 3, pp. 493-500, 1997.

[34] J. P. Mellard, K. Yoshiyama, E. Litchman, and C. A. Klausmeier, "The vertical distribution of phytoplankton in stratified water columns," Journal of Theoretical Biology, vol. 269, no. 1, pp. 16-30, 2011.

[35] H. Piazena, E. Perez-Rodrigues, D. P. Häder, and F. LopezFigueroa, "Penetration of solar radiation into the water column of the central subtropical Atlantic ocean-optical properties and possible biological consequences," Deep-Sea Research II, vol. 49, no. 17, pp. 3513-3528, 2002.

[36] K. Gao, G. Li, E. W. Helbling, and V. E. Villafañe, "Variability of UVR effects on photosynthesis of summer phytoplankton assemblages from a tropical coastal area of the South China sea," Photochemistry and Photobiology, vol. 83, no. 4, pp. 802809, 2007.

[37] C. A. Klausmeier and E. Litchman, "Algal games: the vertical distribution of phytoplankton in poorly mixed water columns," Limnology and Oceanography, vol. 46, no. 8, pp. 1998-2007, 2001.

[38] J. A. Raven, “The role of vacuoles," New Physicist, vol. 106, pp. 357-422, 1987. 

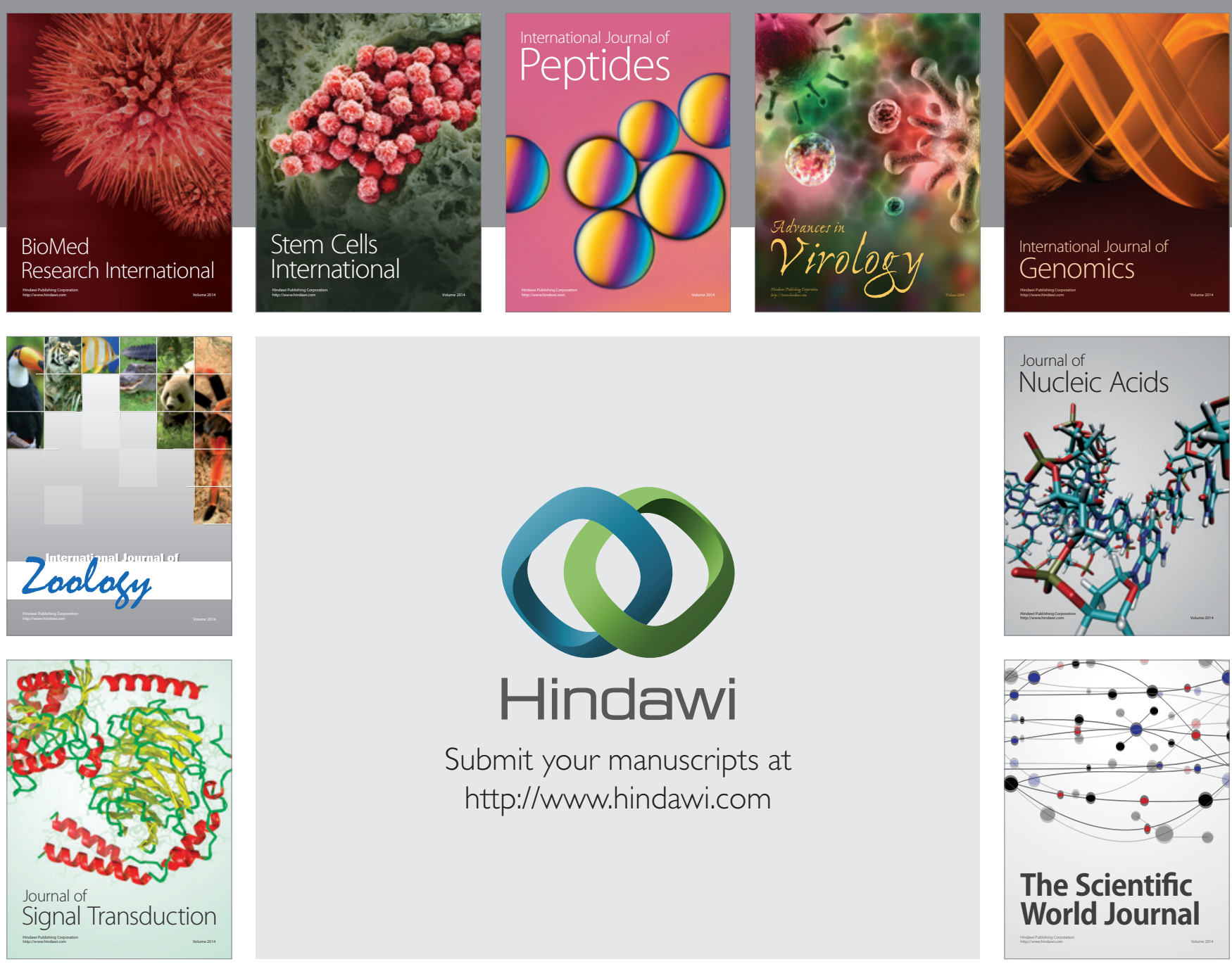

Submit your manuscripts at

http://www.hindawi.com
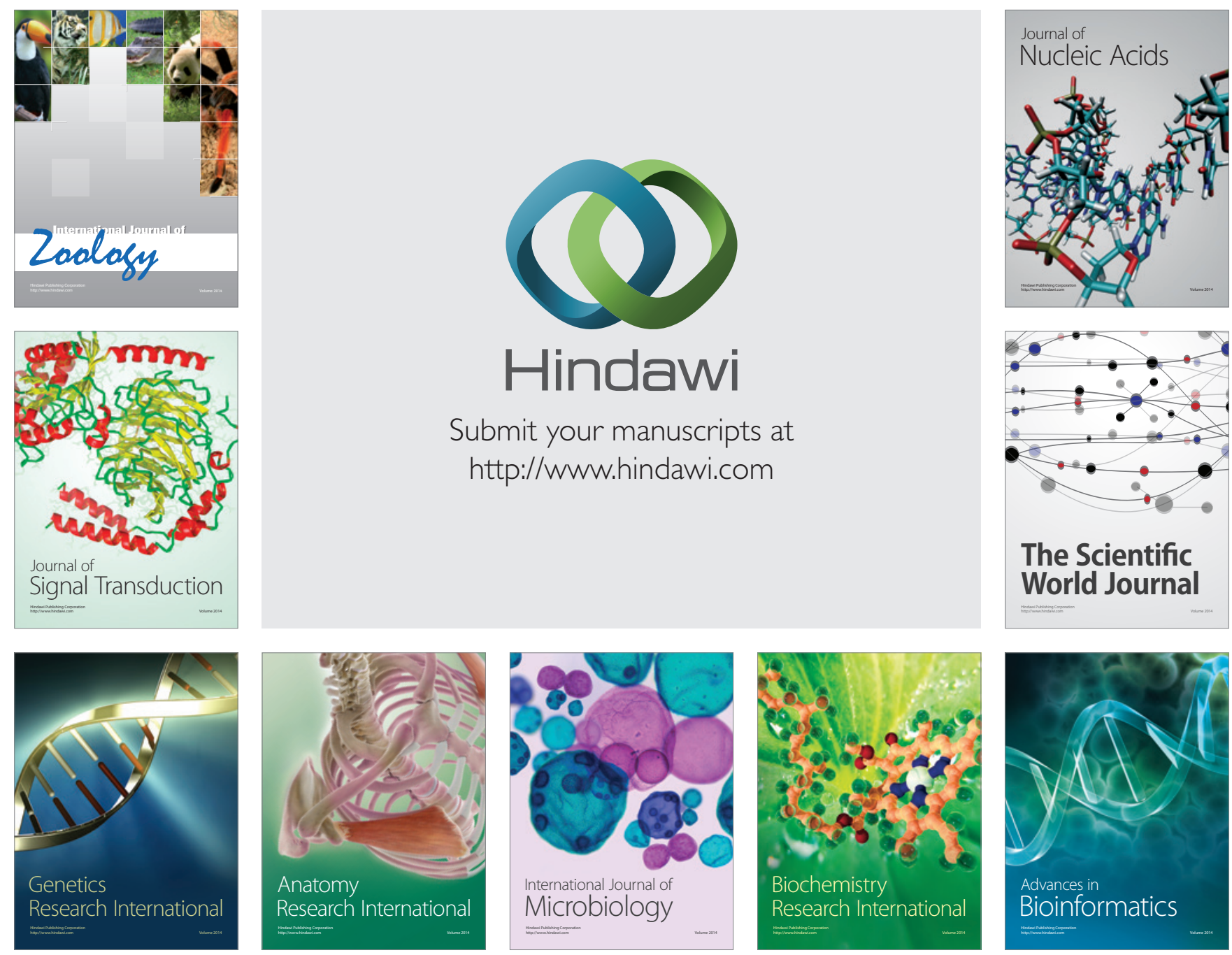

The Scientific World Journal
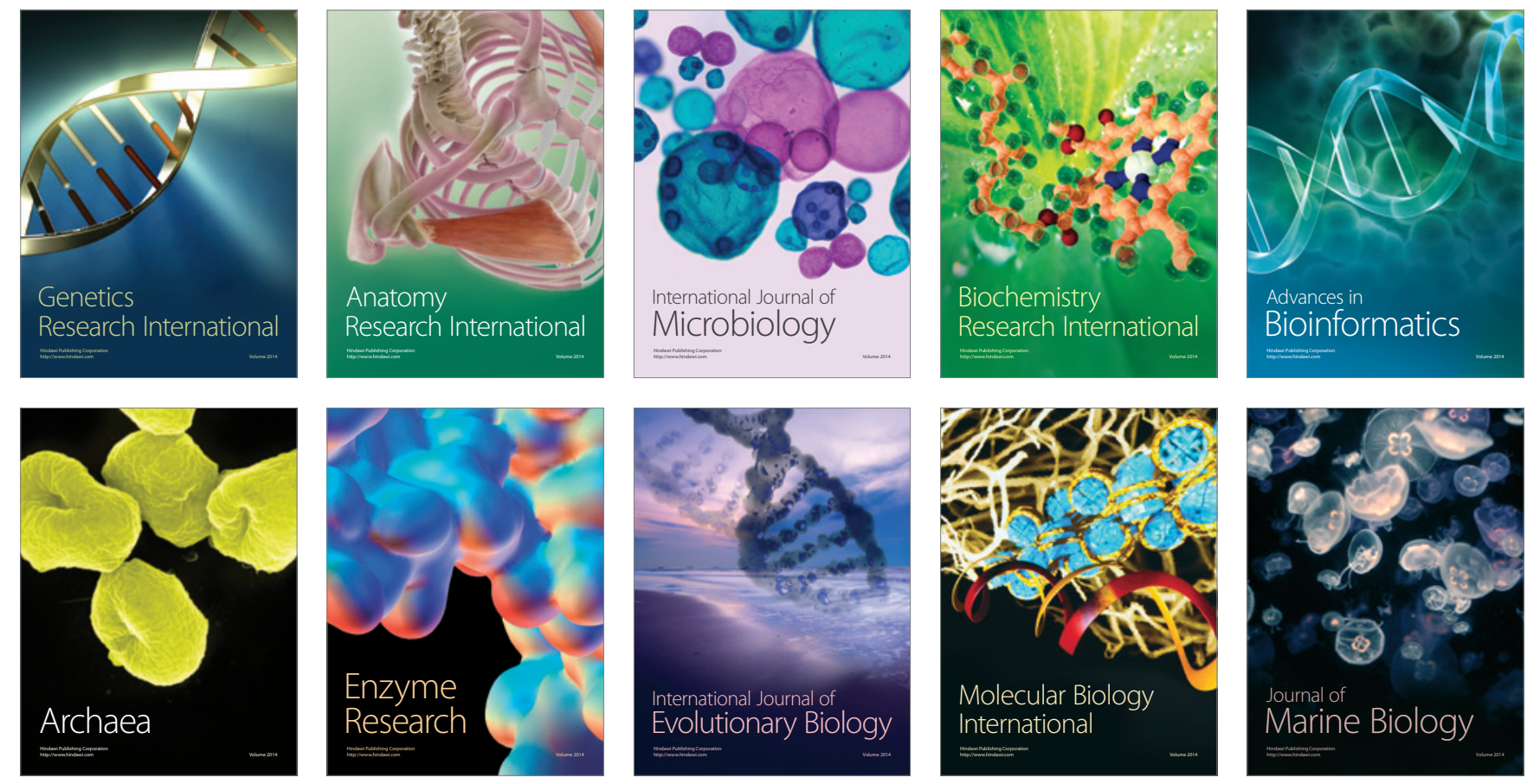